\title{
Sistem Informasi Geografis Pemetaan Sungai dan Bangunan Utama pada Daerah Irigasi Kewenangan Provinsi di Pulau Timor
}

\author{
Christiani Chandra Manubulu \\ christianichandra@gmail.com \\ Frederikus D. Ndouk \\ pratama_ndouk@yahoo.co.id \\ Program Studi Teknik Sipil Universitas Widya Mandira Kupang
}

\begin{abstract}
Water is one of the basic human needs for various daily needs. One source of water that is often used by the general public is river water. With proper utilization, river water can support the economic development of the surrounding community. The main priority for water use is for domestic use such as drinking water and household needs and also used for industrial, agricultural, plantation, livestock, fishery, and so on. Optimal use of rivers for irrigation areas must be supported by information related to river conditions and buildings in rivers. Therefore it is necessary to make a database related to river conditions and irrigation building conditions. One of the software used in making a river database in the Provincial Irrigation Authority on Timor Island is Quantum Geographic Information System (QGIS) because it is open-source software that does not require a license but provides ample room for users to add functions such as software other paid mapping.
\end{abstract}

Keywords: Database, Irrigation Area, QGIS

\section{PENDAHULUAN}

\section{Latar Belakang}

Provinsi Nusa Tenggara Timur merupakan daerah yang bisa dikatakan kurang akan air tetapi merupakan daerah potensial pertanian, karena memiliki lahan dan dataran pertanian yang luas serta sebagian besar penduduknya bermata pencaharian sebagai petani. Di beberapa wilayah di Pulau Timor sendiri terdapat beberapa sungai yang berpotensi untuk dimanfaatkan.

Pembuatan data base sungai bertujuan mengetahui sungai-sungai yang mempunyai potensi besar sebagai sumber air irigasi pada daerah irigasi kewenangan Provinsi sehingga dapat memberi manfaat yang besar bagi masyarakat, sekaligus menjaga kelestarian sungai dan juga mengurangi banjir serta bencana yang sering terjadi akibat adanya penggunaan daerah bantaran sungai yang tidak terkontrol.

Software yang digunakan dalam pembuatan data base sungai pada Daerah Irigasi Kewenangan Provinsi di Pulau Timor adalah Quantum Geographic Information System (QGIS) karena merupakan perangkat lunak opensource yang tidak memerlukan lisensi namun memberikan ruang yang cukup luas bagi user untuk melakukan penambahan fungsi seperti pada software pemetaan berbayar lainnya. 
Secara umum QGIS memiliki kelebihan-kelebihan yang cukup menarik bagi para pengguna, bahkan bagi pemula. Keunggulan dari QGIS antara lain:

1. QGIS adalah perangkat lunak yang merupakan FOSS yang berarti Free and Open Source Software sehingga mudah untuk mengunduh software tersebut. Dan tidak ada biaya yang dibebankan bagi pengguna

2. QGIS dapat dikenakan diberbagai macam perangkat lunak mulai dari Windows, Linux, OS X bahkan juga di perangkat Android Anda. QGIS dapat difungsikan untuk mengolah data-data dari berbagai macam perangkat lunak berbayar. adalah :

Tujuan dari kegiatan pengabdian ini

1. Membuat Sistem Informasi Geografis yang dapat mengelola data dan informasi mengenai kondisi Sungai pada Daerah Irigasi Kewenangan Provinsi di Pulau Timor.

2. Membuat Sistem Informasi Geografis yang dapat menampilkan lokasi sebaran dan informasi mengenai Bangunan Irigasi yang masuk dalam Kewenangan Provinsi di Pulau Timor.

\section{METODOLOGI PELAKSANAAN}

Pelaksaan kegiatan pengabdian kepada masyarakat ini terdiri dari empat tahapan yaitu :

1. Pengumpulan data

2. Inventarisasi dan identifikasi lapangan

3. Inputing data hasil inventarisasi dan identifikasi lapangan

4. Pembuatan database sungai

5. Sosialisasi Hasil Identifikasi dan Inventarisasi serta pelatihan penggunaan Data Base dengan Instansi Pengguna

Bagan alir metodologi pelaksanaan kegiatan pengabdian ini dapat dilihat pada Gambar 3.1.

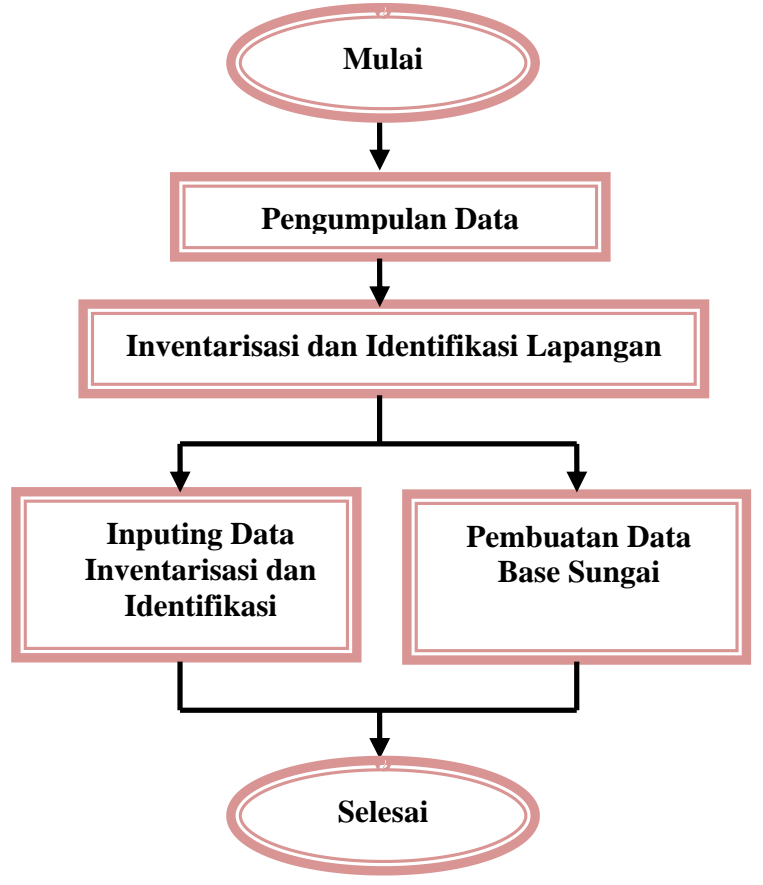

Gambar 3.1 Bagan Alir Pelaksanaan

\section{Pengumpulan Data}

Data Daerah Irigasi Kewenangan Provinsi di Pulau Timor mengacu pada Peraturan Menteri Pekerjaan Umum dan Perumahan Rakyat Republik Indonesia Nomor 14/PRT/M/2015 Tentang Kriteria dan Penetapan Status Daerah Irigasi.

Berdasarkan informasi yang diperoleh dari Dinas Pekerjaan Umum dan Penataan Ruang Provinsi NTT Bidang OP SDA dan Irigasi maka Daerah Irigasi Kewenangan Provinsi yang ada di Pulau Timor dapat dilihat pada Tabel 4.1 mengacu pada Peraturan Menteri Pekerjaan Umum dan Perumahan Rakyat Republik Indonesia Nomor 14/PRT/M/2015 Tentang Kriteria dan Penetapan Status Daerah Irigasi.

Dalam Tabel 4.1 yang diberikan mencakup daerah irigasi kewenangan provinsi saja namun belum mencakup sub daerah irigasi, sehingga dalam kegiatan Studi Data Base Sungai Pada Daerah Irigasi Kewenangan Provinsi, tidak hanya meninjau Daerah Irigasi utama saja tetapi juga meninjau Sub Daerah Irigasi Kewenangan Provinsi yang ada di Pulau Timor. 
Tabel 4.1 Daerah Irigasi Kewenangan Provinsi NTT di Pulau Timor

\begin{tabular}{|c|l|c|}
\hline No & $\begin{array}{l}\text { Provinsi/ Kabupaten/ } \\
\text { KotaNama Daerah Irigasi } \\
\text { Permukaan }\end{array}$ & $\begin{array}{c}\text { Jumlah } \\
(\mathbf{H a})\end{array}$ \\
\hline A. & Lintas Kabupaten/Kota & $\mathbf{4 6 7 2}$ \\
\hline 1. & D.I. Batu Putih/Oebobo & 400 \\
\hline 2. & D.I. Biliuana & 1430 \\
\hline 3. & D.I. Hasfuik & 1600 \\
\hline 4. & D.I Aroki & 1242 \\
\hline B. & Utuh Kabupaten/Kota & 13505 \\
\hline B1. & Kabupaten Belu & \\
\hline 1. & D.I. Fatu Besi & 1650 \\
\hline 2. & D.I Maubusa & 1350 \\
\hline 3. & D.I Obor & 1815 \\
\hline B2 & Kabupaten Kupang & 1100 \\
\hline 1. & D.I Enorain & 1071 \\
\hline 2. & D.I Kolidoki & 1350 \\
\hline 3. & D.I Netenmanu & \\
\hline B3 & Kabupaten Malaka & 1650 \\
\hline 1. & D.I Alas & 1000 \\
\hline 2. & D.I Weliman & 1089 \\
\hline B4 & Kabupaten TTS & \\
\hline 1. & D.I Oebelo & 1430 \\
\hline B5 & Kabupaten TTU & \\
\hline 1. & D.I Ponu & \\
\hline & Sumber : Permen Nomor 14/PRT/M/2015 \\
\hline & & \\
\hline
\end{tabular}

\section{Inventarisasi dan identifikasi lapangan}

Setelah di peroleh data Daerah Irigasi yang masuk dalam Kewenangan Provinsi maka di lakukan Inventarisasi dan Identifikasi Lapangan untuk Daerah Irigasi yang sumber airnya berasal dari sungai. Peninjauan lapangan bertujuan untuk memperoleh melakukan pemantauan terhadap sifat sungai antara lain debit sungai, ph sungai dan tinggi banjir serta mendapat data mengenai bangunan irigasi berupa lokasi bangunan, tahun dibangun, jarak bangunan utama dari hulu, dan juga debit pengambilan. Hasil inventarisasi kemudian di input dan dilakukan pembuatan data base yang menampilkan informasi mengenai sungai dan bangunan irigasi utama.

Dari data Daerah Irigasi yang ada di Pulau Timor, diperoleh data sungai-sungai yang kamudian akan diidentifikasi dan diinventarisasi bangunan-bangunan yang ada di sungai terkhususnya bangunanbangunan yang berkaitan langsung dengan irigasi yang membawa atau mengalirkan air dari sungai menuju petak irigasi.
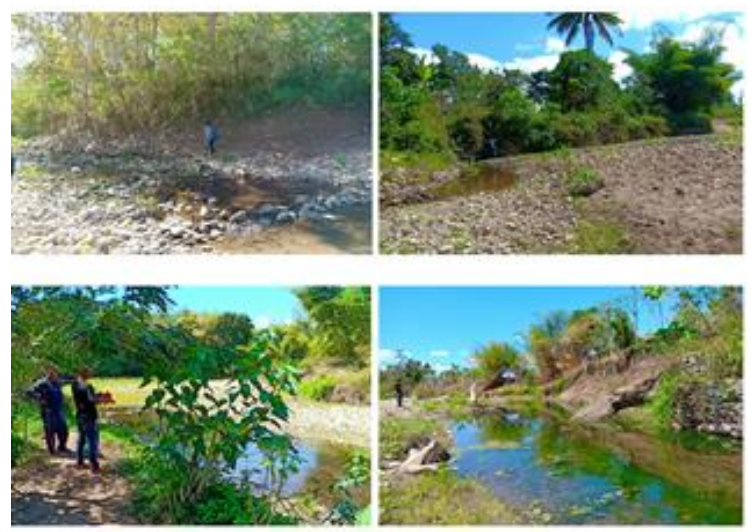

Gambar 3.2Lokasi Sekitar Sungai Noe Bemes
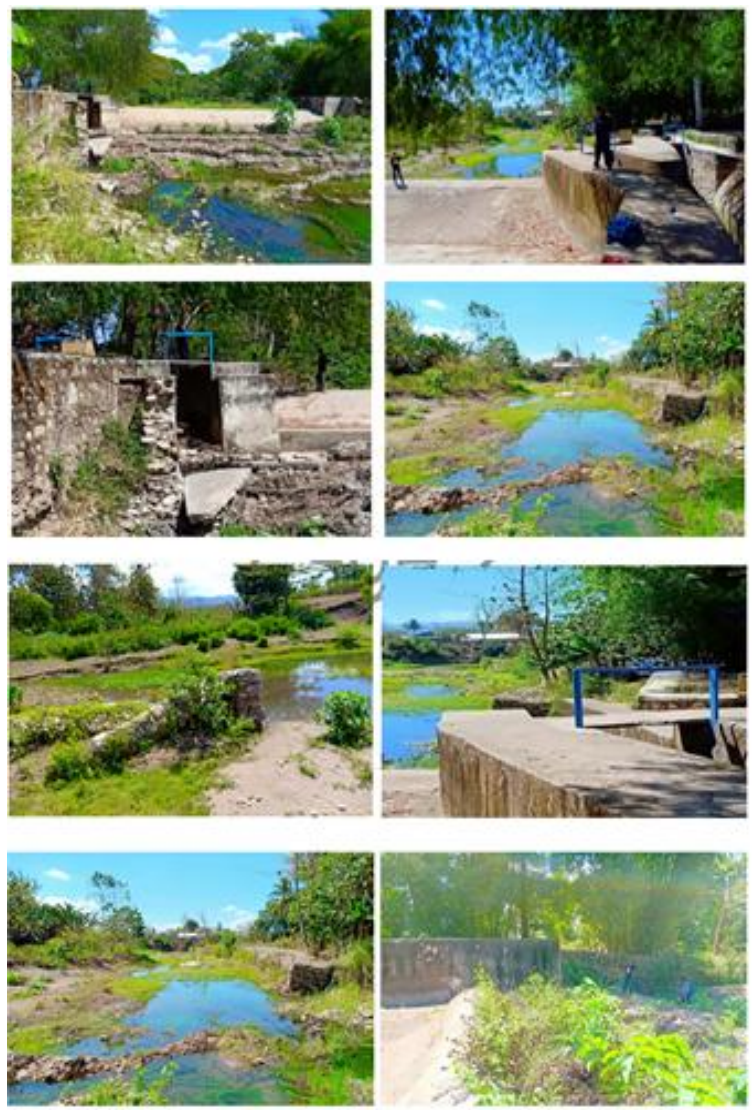

Gambar 3.3Bendung Hauteas 


\section{Inputing Data Hasil Inventarisasi dan Identifikasi Sungai dan Bangunan Utama}

Berdasarkan Data Permen Nomor 14/ PRT/M/2015 dan data yang diperoleh dari Dinas Pekerjaan Umum dan Penataan Ruang menyangkut penetapan Daerah Irigasi yang masuk dalam kewenangan Provinsi baik Daerah Irigasi dan Sub Daerah Irigasi maka dilakukan peninjauan lokasi dan untuk memperoleh data lokasi bangunan utama untuk Daerah Irigasi sebagaimana dapat dilihat pada Tabel 4.2.

Tabel 4.2 Inventarisasi bangunan utama pada Daerah Irigasi Kewenangan Provinsi NTT di Pulau Timor

\begin{tabular}{|c|c|c|c|}
\hline No. & $\begin{array}{c}\text { Nama Daerah } \\
\text { Irigasi }\end{array}$ & Nama Sub D.I & Kab. \\
\hline \multirow[t]{3}{*}{1} & D.I Batu Putih & D.I. Batu Putih & TTS \\
\hline & & D.I. Oebobo & TTS \\
\hline & & D.I. Noeleke & TTS \\
\hline 2 & D.I. Biliuana & D.I. Biliuana & TTU \\
\hline 3 & D.I. Hasfuik & D.I. Hasfuik & TTU \\
\hline \multirow[t]{5}{*}{4} & D.I. Aroki & D.I. Aroki & Malaka \\
\hline & & D.I. Hauteas & TTU \\
\hline & & $\begin{array}{l}\text { D.I. } \\
\text { Tuasene/Mil'ana }\end{array}$ & TTU \\
\hline & & D.I. Oekopa & TTU \\
\hline & & $\begin{array}{l}\text { D.I. } \\
\text { Boronubaen }\end{array}$ & TTU \\
\hline 5 & D.I. Enorain & D.I. Enoraen & Kupang \\
\hline \multirow[t]{2}{*}{6} & $\begin{array}{l}\text { D.I. } \\
\text { Netenmanu }\end{array}$ & D.I. Netenmanu & Kupang \\
\hline & & D.I. Noelfael & Kupang \\
\hline \multirow[t]{2}{*}{7} & D.I. Kolidoki & D.I. Kolidoki & Kupang \\
\hline & & D.I. Kiutasik & Kupang \\
\hline 8 & D.I. Oebelo & D.I. Oebelo & TTS \\
\hline 9 & D.I. Ponu & D.I. Ponu & TTU \\
\hline 10 & D.I. Fatubesi & D.I. Fatubesi & Belu \\
\hline 11 & D.I. Maubusa & D.I Debuklaran & Belu \\
\hline \multirow[t]{2}{*}{12} & D.I Obor & D.I. Obor 1 & Belu \\
\hline & & D.I. Rinbesihat & TTU \\
\hline \multirow[t]{2}{*}{13} & D.I. Alas & D.I. Nularan & Malaka \\
\hline & & D.I. Monukren & Malaka \\
\hline 14 & D.I. Weliman & D.I. Weliman & Malaka \\
\hline
\end{tabular}

Berdasarkan lokasi bangunan utama yang sudah diperoleh, maka dapat di identifikasi sungai-sungai yang menjadi sumber air utama bagi daerah irigasi. Data sungai yang berkaitan dengan daerah irigasi kewengan provinsi di Pulau Timor dapat dilihat pada Tabel 4.3. Konsultan melakukan identifikasi terhadap sungai, dan data yang diperoleh antara lain dapat panjang sungai, mutu air yang diukur menggunakan ph meter, debit sungai dan tinggi banjir.

Tabel 4.3 Data Sungai pada Daerah Irigasi Kewenangan Provinsi NTT di Pulau Timor

\begin{tabular}{|c|c|c|c|}
\hline No. & $\begin{array}{c}\text { Nama } \\
\text { Daerah } \\
\text { Irigasi }\end{array}$ & $\begin{array}{c}\text { Nama Sub } \\
\text { D.I }\end{array}$ & $\begin{array}{l}\text { Nama } \\
\text { Sungai }\end{array}$ \\
\hline \multirow[t]{3}{*}{1} & $\begin{array}{l}\text { D.I Batu } \\
\text { Putih }\end{array}$ & $\begin{array}{l}\text { D.I. Batu } \\
\text { Putih }\end{array}$ & Wentuka \\
\hline & & D.I. Oebobo & Meto \\
\hline & & D.I. Noeleke & Leke \\
\hline 2 & $\begin{array}{l}\text { D.I. } \\
\text { Biliuana }\end{array}$ & D.I. Biliuana & Noe Muti \\
\hline 3 & $\begin{array}{l}\text { D.I. } \\
\text { Hasfuik }\end{array}$ & D.I. Hasfuik & $\begin{array}{l}\text { Mota } \\
\text { Hasfuik }\end{array}$ \\
\hline \multirow[t]{5}{*}{4} & D.I. Aroki & D.I. Aroki & Nono Bau \\
\hline & & D.I. Hauteas & Noe Bemes \\
\hline & & D.I. Tuasene & Noe Naitanu \\
\hline & & D.I. Oekopa & $\begin{array}{l}\text { Mota } \\
\text { Oenalic }\end{array}$ \\
\hline & & $\begin{array}{l}\text { D.I. } \\
\text { Boronubaen }\end{array}$ & Noe Bemes \\
\hline 5 & $\begin{array}{l}\text { D.I. } \\
\text { Enorain }\end{array}$ & D.I. Enoraen & Noel Mina \\
\hline \multirow[t]{2}{*}{6} & $\begin{array}{l}\text { D.I. } \\
\text { Netenmanu }\end{array}$ & $\begin{array}{l}\text { D.I. } \\
\text { Netenmanu }\end{array}$ & Lelo \\
\hline & & D.I. Noelfael & Noelfael \\
\hline \multirow[t]{2}{*}{7} & $\begin{array}{l}\text { D.I. } \\
\text { Kolidoki } \\
\end{array}$ & D.I. Kolidoki & $\begin{array}{l}\text { Noel } \\
\text { Puames }\end{array}$ \\
\hline & & D.I. Kiutasik & Noel Jabe \\
\hline 8 & D.I. Oebelo & D.I. Oebelo & Noe Oebaki \\
\hline 9 & D.I. Ponu & D.I. Ponu & Mota Ponu \\
\hline 10 & $\begin{array}{l}\text { D.I. } \\
\text { Fatubesi }\end{array}$ & D.I. Fatubesi & $\begin{array}{l}\text { Mota } \\
\text { Baukama }\end{array}$ \\
\hline 11 & $\begin{array}{l}\text { D.I. } \\
\text { Maubusa }\end{array}$ & $\begin{array}{l}\text { D.I } \\
\text { Debuklaran }\end{array}$ & Mota Merak \\
\hline \multirow[t]{2}{*}{12} & D.I Obor & D.I. Obor 1 & Mota Mauk \\
\hline & & $\begin{array}{l}\text { D.I. } \\
\text { Rinbesihat }\end{array}$ & $\begin{array}{l}\text { Noe } \\
\text { Oanaumu }\end{array}$ \\
\hline 13 & D.I. Alas & D.I. Nularan & Mota Koke \\
\hline
\end{tabular}




\begin{tabular}{|c|l|l|l|}
\hline No. & $\begin{array}{c}\text { Nama } \\
\text { Daerah } \\
\text { Irigasi }\end{array}$ & \multicolumn{1}{|c|}{$\begin{array}{c}\text { Nama Sub } \\
\text { D.I }\end{array}$} & $\begin{array}{c}\text { Nama } \\
\text { Sungai }\end{array}$ \\
\hline 14 & $\begin{array}{l}\text { D.I. } \\
\text { Weliman }\end{array}$ & D.I. Monukren & Mota Siwi \\
\hline
\end{tabular}

Tabel 4.4 HasilInventarisasi Sungai

\begin{tabular}{|c|c|c|c|c|c|}
\hline $\begin{array}{l}\mathbf{N} \\
\mathbf{0}\end{array}$ & $\begin{array}{l}\text { Nama } \\
\text { Sungai }\end{array}$ & $\begin{array}{c}\text { Panjang } \\
\text { Sungai } \\
(\mathrm{km})\end{array}$ & $\mathbf{P h}$ & $\begin{array}{l}\text { Debit } \\
\left(\mathrm{m}^{3} / \mathrm{d}\right. \\
\text { etik })\end{array}$ & $\begin{array}{c}\text { Tinggi } \\
\text { Banjir } \\
\text { (m) }\end{array}$ \\
\hline 1 & Wentuka & 10.48 & 8.2 & 0.534 & $2,38 \mathrm{~m}$ \\
\hline 2 & Meto & 24.60 & Kering & $\begin{array}{c}\text { Kerin } \\
\mathrm{g}\end{array}$ & $3,14 \mathrm{~m}$ \\
\hline 3 & Leke & 28.40 & 8.4 & 0.239 & $3,98 \mathrm{~m}$ \\
\hline 4 & Noe Muti & 47.15 & 7.9 & 1.163 & $1,31 \mathrm{~m}$ \\
\hline 5 & $\begin{array}{l}\text { Mota } \\
\text { Hasfuik }\end{array}$ & 16.09 & 7.6 & 0.709 & $2,95 \mathrm{~m}$ \\
\hline 6 & Nono Bau & 17.52 & 8.3 & 0.256 & $2,01 \mathrm{~m}$ \\
\hline 7 & $\begin{array}{l}\text { Noe } \\
\text { Bemes } \\
\end{array}$ & 11.18 & 8.8 & 0.042 & $3,29 \mathrm{~m}$ \\
\hline 8 & $\begin{array}{l}\text { Noe } \\
\text { Naitanu } \\
\end{array}$ & 4.10 & 7.8 & 0.022 & $3,04 \mathrm{~m}$ \\
\hline 9 & $\begin{array}{l}\text { Mota } \\
\text { Oenalic }\end{array}$ & 4.80 & 8.9 & 0.033 & $3,27 \mathrm{~m}$ \\
\hline 10 & Noel Mina & 59.68 & 6.5 & 0.936 & $3,60 \mathrm{~m}$ \\
\hline 11 & Lelo & 16.65 & 7.7 & 0.101 & $1,75 \mathrm{~m}$ \\
\hline 12 & Noelfael & 36.69 & 8.8 & 0.479 & $1,45 \mathrm{~m}$ \\
\hline 13 & $\begin{array}{l}\text { Noel } \\
\text { Puames } \\
\end{array}$ & 18.99 & Kering & $\begin{array}{c}\text { Kerin } \\
\mathrm{g}\end{array}$ & $2,70 \mathrm{~m}$ \\
\hline 14 & Noel Jabe & 12.85 & Kering & $\begin{array}{c}\text { Kerin } \\
\mathrm{g}\end{array}$ & $3,15 \mathrm{~m}$ \\
\hline 15 & $\begin{array}{l}\text { Noe } \\
\text { Oebaki }\end{array}$ & 20.66 & Kering & $\begin{array}{c}\text { Kerin } \\
\mathrm{g}\end{array}$ & $4,52 \mathrm{~m}$ \\
\hline 16 & $\begin{array}{l}\text { Mota } \\
\text { Ponu }\end{array}$ & 15.60 & 7.2 & 0.601 & $3,34 \mathrm{~m}$ \\
\hline 17 & $\begin{array}{l}\text { Mota } \\
\text { Baukama }\end{array}$ & 21.20 & 7.8 & 0.057 & $1,82 \mathrm{~m}$ \\
\hline 18 & $\begin{array}{l}\text { Mota } \\
\text { Merak }\end{array}$ & 18.39 & 8.9 & 0.084 & $2,20 \mathrm{~m}$ \\
\hline 19 & $\begin{array}{l}\text { Mota } \\
\text { Mauk }\end{array}$ & 19.78 & 9.1 & 0.302 & $2,69 \mathrm{~m}$ \\
\hline 20 & $\begin{array}{l}\text { Noe } \\
\text { Oanaumu }\end{array}$ & 8.90 & 7.8 & 0.041 & $4,25 \mathrm{~m}$ \\
\hline 21 & $\begin{array}{l}\text { Mota } \\
\text { Koke }\end{array}$ & 11.06 & Kering & $\begin{array}{c}\text { Kerin } \\
\mathrm{g}\end{array}$ & $2,38 \mathrm{~m}$ \\
\hline 22 & Mota Siwi & 13.19 & Kering & $\begin{array}{c}\text { Kerin } \\
\mathrm{g}\end{array}$ & $3,78 \mathrm{~m}$ \\
\hline 23 & $\begin{array}{l}\text { Mota } \\
\text { Benanain }\end{array}$ & 46.80 & 8.0 & 4.500 & $5,20 \mathrm{~m}$ \\
\hline
\end{tabular}

Dari total 23 (dua puluh tiga) sungai yang berkaitan denganDaerah Irigasi Kewenangan Propinsi yang terdapat pada Tabel 4.3, maka dilakukan inventarisasi dan identifikasi terkait bangunan-bangunan disekitaran sungai tersebut.
Berdasarkan Data Permen Nomor 14/ PRT/M/2015 hanya diberikan lokasi Daerah Irigasi namun tidak terdapat Informasi mengenai bangunan irigasi utamasehingga dilakukan pencarian titik koordinat lokasi Bangunan Irigasi. Koordinat Bangunan Irigasi dapat dilihat pada Tabel 4.5.

Tebel 4.5 Koordinat Bangunan Irigasi

\begin{tabular}{|c|c|c|c|}
\hline \multirow{2}{*}{$\begin{array}{l}\text { Nama } \\
\text { Sungai }\end{array}$} & \multirow{2}{*}{$\begin{array}{l}\text { Nama } \\
\text { Objek }\end{array}$} & \multicolumn{2}{|c|}{ Koordinat Bangunan } \\
\hline & & Latitude & Longitude \\
\hline Wentuka & $\begin{array}{l}\text { Bendung } \\
\text { Wentuka }\end{array}$ & $9^{\circ} 58^{\prime} 45.81 " \mathrm{~S}$ & $124^{\circ} 9^{\prime} 33.17^{\prime \prime T}$ \\
\hline Meto & $\begin{array}{l}\text { Bendung } \\
\text { Noemute }\end{array}$ & $9^{\circ} 59^{\prime} 22.01 " \mathrm{~S}$ & $124^{\circ} 10^{\prime} 2.78^{\prime \prime T}$ \\
\hline Leke & $\begin{array}{l}\text { Bendung } \\
\text { Noeleke }\end{array}$ & $9^{\circ} 57^{\prime} 14.1 " \mathrm{~S}$ & $124^{\circ} 633.3^{\prime \prime T}$ \\
\hline Noe Muti & $\begin{array}{l}\text { Free } \\
\text { Intake } \\
\text { Biliuana }\end{array}$ & $9^{\circ} 35^{\prime} 41.21^{\prime \prime S}$ & $124^{\circ} 22^{\prime} 47.14^{\prime \prime T}$ \\
\hline $\begin{array}{l}\text { Mota } \\
\text { Hasfuik }\end{array}$ & $\begin{array}{l}\text { Bendung } \\
\text { Hasfuik }\end{array}$ & $9^{\circ} 4^{\prime} 38.61 " \mathrm{~S}$ & $124^{\circ} 46^{\prime} 54.98^{\prime \prime} \mathrm{T}$ \\
\hline Nono Bau & $\begin{array}{l}\text { Bendung } \\
\text { Aroki }\end{array}$ & $9^{\circ} 20^{\prime} 48.73 " \mathrm{~S}$ & $124^{\circ} 48^{\prime} 28.06^{\prime \prime T}$ \\
\hline $\begin{array}{l}\text { Noe } \\
\text { Bemes }\end{array}$ & $\begin{array}{l}\text { Bendung } \\
\text { Hauteas }\end{array}$ & $9^{\circ} 17^{\prime} 42.09^{\prime \prime S}$ & $124^{\circ} 50^{\prime} 10.63^{\prime \prime T}$ \\
\hline $\begin{array}{l}\text { Noe } \\
\text { Naitanu } \\
\end{array}$ & $\begin{array}{l}\text { Bendung } \\
\text { Oehendak }\end{array}$ & $9^{\circ} 19^{\prime} 27.04^{\prime \prime S}$ & $124^{\circ} 48^{\prime} 19.48^{\prime \prime T}$ \\
\hline $\begin{array}{l}\text { Mota } \\
\text { Oenalic } \\
\end{array}$ & $\begin{array}{l}\text { Bendung } \\
\text { Soeleak }\end{array}$ & $9^{\circ} 18^{\prime} 44.61 " \mathrm{~S}$ & $124^{\circ} 46^{\prime} 54.73^{\prime \prime T}$ \\
\hline $\begin{array}{l}\text { Noe } \\
\text { Bemes }\end{array}$ & $\begin{array}{l}\text { Free } \\
\text { Intake } \\
\text { Oetifan }\end{array}$ & $9^{\circ} 17^{\prime} 52.41 " \mathrm{~S}$ & $124^{\circ} 50^{\prime} 17.71 " \mathrm{~T}$ \\
\hline Noel Mina & $\begin{array}{l}\text { Free } \\
\text { Intake } \\
\text { Oemoro }\end{array}$ & $10^{\circ} 6 ' 29.50 " \mathrm{~S}$ & $124^{\circ} 11^{\prime} 54.00^{\prime \prime} \mathrm{T}$ \\
\hline Lelo & $\begin{array}{l}\text { Free } \\
\text { Intake } \\
\text { Oelelo }\end{array}$ & $9^{\circ} 24^{\prime} 47.50^{\prime \prime S}$ & $124^{\circ} 5^{\prime} 32.70^{\prime \prime} \mathrm{T}$ \\
\hline Noelfael & $\begin{array}{l}\text { Free } \\
\text { Intake } \\
\text { Noelfael }\end{array}$ & $9^{\circ} 26^{\prime} 40.7 " \mathrm{~S}$ & $124^{\circ} 04^{\prime} 53.6^{\prime \prime T}$ \\
\hline $\begin{array}{l}\text { Noel } \\
\text { Puames }\end{array}$ & $\begin{array}{l}\text { Bendung } \\
\text { Kolidoki }\end{array}$ & $10^{\circ} 5^{\prime} 44.90 " \mathrm{~S}$ & $123^{\circ} 53^{\prime} 41.60^{\prime \prime T}$ \\
\hline Noel Jabe & $\begin{array}{l}\text { Bendung } \\
\text { Kiutasik }\end{array}$ & $10^{\circ} 633.49 " \mathrm{~S}$ & $123^{\circ} 54^{\prime} 43.53^{\prime \prime T}$ \\
\hline $\begin{array}{l}\text { Noe } \\
\text { Oebaki }\end{array}$ & $\begin{array}{l}\text { Free } \\
\text { Intake } \\
\text { Toefau }\end{array}$ & $10^{\circ} 6^{\prime} 49.19 " \mathrm{~S}$ & $124^{\circ} 19^{\prime} 15.75^{\prime \prime T}$ \\
\hline $\begin{array}{l}\text { Mota } \\
\text { Ponu }\end{array}$ & $\begin{array}{l}\text { Bendung } \\
\text { Ponu }\end{array}$ & $9^{\circ} 8^{\prime} 32.97 " \mathrm{~S}$ & $124^{\circ} 40^{\prime} 30.01^{\prime \prime T}$ \\
\hline $\begin{array}{l}\text { Mota } \\
\text { Baukama }\end{array}$ & $\begin{array}{l}\text { Bendung } \\
\text { Fatubesi }\end{array}$ & $9^{\circ} 9^{\prime} 8.70^{\prime \prime S}$ & $125^{\circ} 0^{\prime} 28.40^{\prime \prime} \mathrm{T}$ \\
\hline $\begin{array}{l}\text { Mota } \\
\text { Merak }\end{array}$ & $\begin{array}{l}\text { Bendung } \\
\text { Mota } \\
\text { Merak }\end{array}$ & $9^{\circ} 9^{\prime} 53.67 " \mathrm{~S}$ & $124^{\circ} 59^{\prime} 19.01 " \mathrm{~T}$ \\
\hline $\begin{array}{l}\text { Mota } \\
\text { Mauk } \\
\end{array}$ & $\begin{array}{l}\text { Bendung } \\
\text { Mota }\end{array}$ & $9^{\circ} 18^{\prime} 55.90^{\prime \prime S}$ & $124^{\circ} 51^{\prime} 21.80^{\prime \prime} \mathrm{T}$ \\
\hline
\end{tabular}




\begin{tabular}{|c|c|c|c|}
\hline \multirow{2}{*}{$\begin{array}{l}\text { Nama } \\
\text { Sungai }\end{array}$} & \multirow{2}{*}{$\begin{array}{l}\text { Nama } \\
\text { Objek }\end{array}$} & \multicolumn{2}{|c|}{ Koordinat Bangunan } \\
\hline & & Latitude & Longitude \\
\hline & mauk & & \\
\hline $\begin{array}{l}\text { Noe } \\
\text { Oanaumu }\end{array}$ & $\begin{array}{l}\text { Bendung } \\
\text { Oerenbesi }\end{array}$ & $9^{\circ} 20^{\prime} 55.58^{\prime \prime S}$ & $124^{\circ} 47^{\prime} 20.36^{\prime \prime T}$ \\
\hline $\begin{array}{l}\text { Mota } \\
\text { Koke } \\
\end{array}$ & $\begin{array}{l}\text { Bendung } \\
\text { Nularan } \\
\end{array}$ & $9^{\circ} 28^{\prime} 51.74 " \mathrm{~S}$ & $125^{\circ} 1{ }^{\prime} 5.20 " \mathrm{~T}$ \\
\hline Mota Siwi & $\begin{array}{l}\text { Bendung } \\
\text { Motadelek }\end{array}$ & $9^{\circ} 29^{\prime} 50.21 " \mathrm{~S}$ & $124^{\circ} 57^{\prime} 26.18^{\prime \prime T}$ \\
\hline $\begin{array}{l}\text { Mota } \\
\text { Benanain }\end{array}$ & $\begin{array}{l}\text { Bendung } \\
\text { Benanain }\end{array}$ & $9^{\circ} 34^{\prime} 8.91 " \mathrm{~S}$ & $124^{\circ} 50^{\prime} 29.76^{\prime \prime T}$ \\
\hline
\end{tabular}

Berdasarkan koordinat lokasi Bangunan Utama dari hasil peninjauan lokasi, maka lokasi administratif Bangunan Irigasi Utama dapat dilihat pada Tabel 4.6.

Tabel 4.6 Lokasi administratif Bangunan Irigasi Utama

\begin{tabular}{|c|c|c|c|}
\hline $\begin{array}{l}\text { Nama } \\
\text { Objek }\end{array}$ & Ds./Kel. & Kec. & Kab. \\
\hline $\begin{array}{l}\text { Bendung } \\
\text { Wentuka }\end{array}$ & Ds. Oebobo & $\begin{array}{l}\text { Kec. Batu } \\
\text { Putih }\end{array}$ & TTS \\
\hline $\begin{array}{l}\text { Bendung } \\
\text { Noemute }\end{array}$ & Ds. Mio & $\begin{array}{l}\text { Kec. } \\
\text { Amanuban } \\
\text { Selatan }\end{array}$ & TTS \\
\hline $\begin{array}{l}\text { Bendung } \\
\text { Noeleke }\end{array}$ & Ds. Koa & $\begin{array}{l}\text { Kec. Mollo } \\
\text { Barat }\end{array}$ & TTS \\
\hline $\begin{array}{l}\text { Free Intake } \\
\text { Biliuana }\end{array}$ & $\begin{array}{l}\text { Ds. } \\
\text { Fatunisuan }\end{array}$ & $\begin{array}{l}\text { Momafo } \\
\text { barat }\end{array}$ & TTU \\
\hline $\begin{array}{l}\text { Bendung } \\
\text { Hasfuik }\end{array}$ & $\begin{array}{l}\text { Ds. } \\
\text { Nonotbatan }\end{array}$ & $\begin{array}{l}\text { Kec. Biboki } \\
\text { Anleu }\end{array}$ & TTU \\
\hline $\begin{array}{l}\text { Bendung } \\
\text { Aroki }\end{array}$ & Ds. Meotroy & $\begin{array}{l}\text { Kec. } \\
\text { Laenmanen }\end{array}$ & Malaka \\
\hline $\begin{array}{l}\text { Bendung } \\
\text { Hauteas }\end{array}$ & Ds. Hauteas & $\begin{array}{l}\text { Kec. Biboki } \\
\text { Utara }\end{array}$ & TTU \\
\hline $\begin{array}{l}\text { Bendung } \\
\text { Oehendak }\end{array}$ & Ds. Oekopa & $\begin{array}{l}\text { Kec. Biboki } \\
\text { Tanpah }\end{array}$ & TTU \\
\hline $\begin{array}{l}\text { Bendung } \\
\text { Soeleak }\end{array}$ & Ds. Taunbaen & $\begin{array}{l}\text { Kec. Biboki } \\
\text { Utara }\end{array}$ & TTU \\
\hline $\begin{array}{l}\text { Free Intake } \\
\text { Oetifan }\end{array}$ & $\begin{array}{l}\text { Kel. } \\
\text { Boronubaen }\end{array}$ & $\begin{array}{l}\text { Kec. Biboki } \\
\text { Utara } \\
\end{array}$ & TTU \\
\hline $\begin{array}{l}\text { Free Intake } \\
\text { Oemoro }\end{array}$ & Ds. Enoraen & $\begin{array}{l}\text { Kec. Amarasi } \\
\text { Timur }\end{array}$ & Kupang \\
\hline $\begin{array}{l}\text { Free Intake } \\
\text { Oelelo }\end{array}$ & $\begin{array}{l}\text { Ds. } \\
\text { Netenmanu } \\
\text { Utara } \\
\end{array}$ & $\begin{array}{l}\text { Kec. } \\
\text { Amfoang } \\
\text { Timur }\end{array}$ & Kupang \\
\hline $\begin{array}{l}\text { Free Intake } \\
\text { Noelfael }\end{array}$ & $\begin{array}{l}\text { Ds. } \\
\text { Netenmanu } \\
\text { Utara }\end{array}$ & $\begin{array}{l}\text { Kec. } \\
\text { Amfoang } \\
\text { Timur }\end{array}$ & Kupang \\
\hline $\begin{array}{l}\text { Bendung } \\
\text { Kolidoki }\end{array}$ & Ds. Pukdale & $\begin{array}{l}\text { Kec. Kupang } \\
\text { Timur }\end{array}$ & Kupang \\
\hline $\begin{array}{l}\text { Bendung } \\
\text { Kiutasik }\end{array}$ & Ds. Raknamo & $\begin{array}{l}\text { Kec. Amabi } \\
\text { Oefeto }\end{array}$ & Kupang \\
\hline $\begin{array}{l}\text { Free Intake } \\
\text { Toefau }\end{array}$ & Ds. Oebelo & $\begin{array}{l}\text { Kec. } \\
\text { Amanuban } \\
\text { Selatan } \\
\end{array}$ & TTS \\
\hline $\begin{array}{l}\text { Bendung } \\
\text { Ponu }\end{array}$ & Kel. Ponu & $\begin{array}{l}\text { Kec. Biboki } \\
\text { Anleu }\end{array}$ & TTU \\
\hline
\end{tabular}

\begin{tabular}{|l|l|l|l|}
\hline \multicolumn{1}{|c|}{$\begin{array}{c}\text { Nama } \\
\text { Objek }\end{array}$} & \multicolumn{1}{c|}{ Ds./Kel. } & \multicolumn{1}{c|}{ Kec. } & \multicolumn{1}{c|}{ Kab. } \\
\hline $\begin{array}{l}\text { Bendung } \\
\text { Fatubesi }\end{array}$ & Ds. Takirin & $\begin{array}{l}\text { Kec. Tasifeto } \\
\text { Timur }\end{array}$ & Belu \\
\hline $\begin{array}{l}\text { Bendung } \\
\text { Mota Merak }\end{array}$ & Ds. Dafala & $\begin{array}{l}\text { Kec. Tasifeto } \\
\text { Timur }\end{array}$ & Belu \\
\hline $\begin{array}{l}\text { Bendung } \\
\text { Mota mauk }\end{array}$ & Ds. Leuntolu & $\begin{array}{l}\text { Kec. } \\
\text { Raimanuk }\end{array}$ & Belu \\
\hline $\begin{array}{l}\text { Bendung } \\
\text { Oerenbesi }\end{array}$ & Ds. Oerenbesi & $\begin{array}{l}\text { Kec. Biboki } \\
\text { Tanpah }\end{array}$ & TTU \\
\hline $\begin{array}{l}\text { Bendung } \\
\text { Nularan }\end{array}$ & Ds. Rainawe & $\begin{array}{l}\text { Kec. } \\
\text { Kobalima }\end{array}$ & Malaka \\
\hline $\begin{array}{l}\text { Bendung } \\
\text { Motadelek }\end{array}$ & Ds. Lalekun & $\begin{array}{l}\text { Kec. } \\
\text { Kobalima }\end{array}$ & Malaka \\
\hline $\begin{array}{l}\text { Bendung } \\
\text { Benanain }\end{array}$ & Ds. Bakiruk & $\begin{array}{l}\text { Kec. Malaka } \\
\text { Tengah }\end{array}$ & Malaka \\
\hline
\end{tabular}

Setelah diperoleh lokasi Bangunan Irigasi Utama, maka informasi yang diperoleh Informasi mengenai tahun dibangun, debit pengambilan dan jarak bangunan dari hulu sungai. Informasi mengenai Bangunan Utama dapat dilihat pada Tabel 4.7 .

Tabel 4.7 Hasil inventarisasi Bangunan Utama

\begin{tabular}{|l|c|c|c|}
\hline Nama Objek & $\begin{array}{c}\text { Tahun } \\
\text { dibangun }\end{array}$ & $\begin{array}{c}\text { Debit } \\
\text { Saluran } \\
\left(\mathbf{m}^{3} / \text { detik) }\right.\end{array}$ & $\begin{array}{c}\text { Jarak } \\
\text { dari } \\
\text { Hulu } \\
\text { (km) }\end{array}$ \\
\hline $\begin{array}{l}\text { Bendung } \\
\text { Wentuka }\end{array}$ & 1973 & 0.312 & 5.35 \\
\hline $\begin{array}{l}\text { Bendung } \\
\text { Noemute }\end{array}$ & 2000 & Kering & 21.50 \\
\hline $\begin{array}{l}\text { Bendung } \\
\text { Noeleke }\end{array}$ & - & Kering & 26.05 \\
\hline $\begin{array}{l}\text { Free Intake } \\
\text { Biliuana }\end{array}$ & - & 0.020 & 9.86 \\
\hline $\begin{array}{l}\text { Bendung } \\
\text { Hasfuik }\end{array}$ & - & 0.115 & 11.83 \\
\hline $\begin{array}{l}\text { Bendung } \\
\text { Aroki }\end{array}$ & - & 0.106 & 11.00 \\
\hline $\begin{array}{l}\text { Bendung } \\
\text { Hauteas }\end{array}$ & - & 0.003 & 7.68 \\
\hline $\begin{array}{l}\text { Bendung } \\
\text { Oehendak }\end{array}$ & 1979 & 0.015 & 2.84 \\
\hline $\begin{array}{l}\text { Bendung } \\
\text { Soeleak }\end{array}$ & 1981 & 0.016 & 3.83 \\
\hline $\begin{array}{l}\text { Free Intake } \\
\text { Oetifan }\end{array}$ & - & Kering & 7.08 \\
\hline $\begin{array}{l}\text { Free Intake } \\
\text { Oemoro }\end{array}$ & 2007 & Kering & 48.00 \\
\hline $\begin{array}{l}\text { Free Intake } \\
\text { Oelelo }\end{array}$ & - & 0.045 & 15.87 \\
\hline Free Intake & 0.452 & 19.90 \\
\hline
\end{tabular}




\begin{tabular}{|l|c|c|c|}
\hline Nama Objek & $\begin{array}{c}\text { Tahun } \\
\text { dibangun }\end{array}$ & $\begin{array}{c}\text { Debit } \\
\text { Saluran } \\
\left(\mathbf{m}^{3} / \text { detik }\right)\end{array}$ & $\begin{array}{c}\text { Jarak } \\
\text { dari } \\
\text { Hulu } \\
(\mathbf{k m})\end{array}$ \\
\hline Noelfael & - & Kering & 18.08 \\
\hline $\begin{array}{l}\text { Bendung } \\
\text { Kolidoki }\end{array}$ & - & Kering & 8.53 \\
\hline $\begin{array}{l}\text { Bendung } \\
\text { Kiutasik }\end{array}$ & 1971 & Kering & 12.70 \\
\hline $\begin{array}{l}\text { Free Intake } \\
\text { Toefau }\end{array}$ & - & 0.145 & 8.70 \\
\hline Bendung Ponu & - & 0.050 & 10.30 \\
\hline $\begin{array}{l}\text { Bendung } \\
\text { Fatubesi }\end{array}$ & 2006 & 0.040 & 11.79 \\
\hline $\begin{array}{l}\text { Bendung Mota } \\
\text { Merak }\end{array}$ & 2008 & Kering & 7.23 \\
\hline $\begin{array}{l}\text { Bendung Mota } \\
\text { Mauk }\end{array}$ & 2001 & Kering & 9.10 \\
\hline $\begin{array}{l}\text { Bendung } \\
\text { Oerenbesi }\end{array}$ & 0.578 & 13.20 \\
\hline $\begin{array}{l}\text { Bendung } \\
\text { Nularan }\end{array}$ & $\begin{array}{l}\text { Bendung } \\
\text { Motadelek }\end{array}$ & $\begin{array}{l}\text { Bendung } \\
\text { Benanain }\end{array}$ & -098 \\
\hline
\end{tabular}

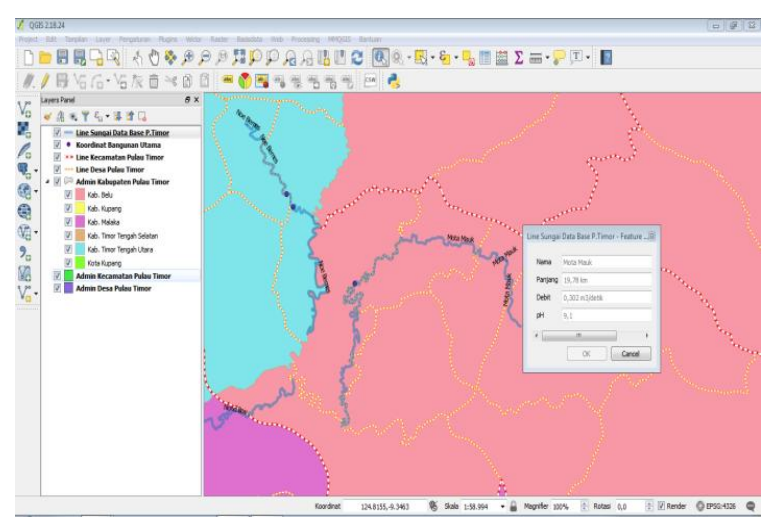

Gambar3.4 Tampilan informasi salah satu sungai pada QGIS

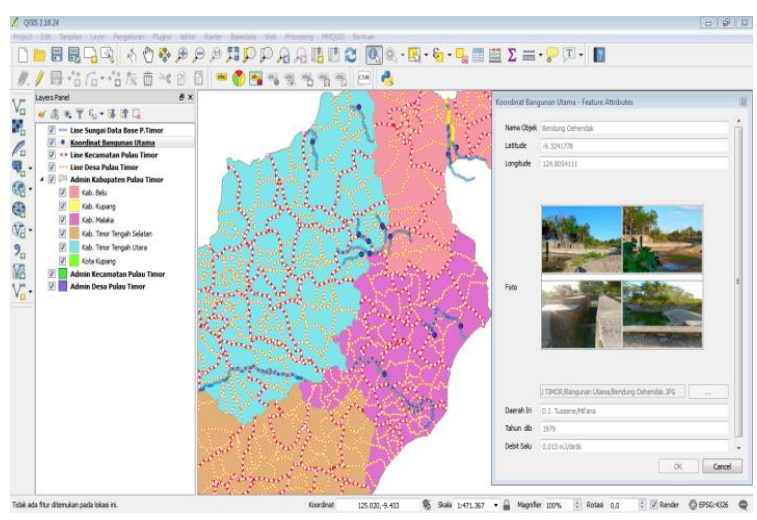

Gambar3.5 Tampilan informasi bangunan utama pada QGIS

\section{Sosialisasi Hasil Identifikasi dan Inventarisasi serta pelatihan penggunaan Data Base dengan Instansi Pengguna}

Setelah dilakukan inventarisasi, identifikasi serta pembuatan sistem informasi geografis sungai dan bangunan utama pada Daerah Irigasi Kewenangan Provinsi di Pulau Timor maka dilakukan sosialisasi dan pelatihan terkait penggunaan produk akhir kepada instansi terkait. Gambar Sosialisasi dan pelatihan penggunaan produk akhir kegiatan pengabdian ini dapat dilihat pada Gambar 4.1 


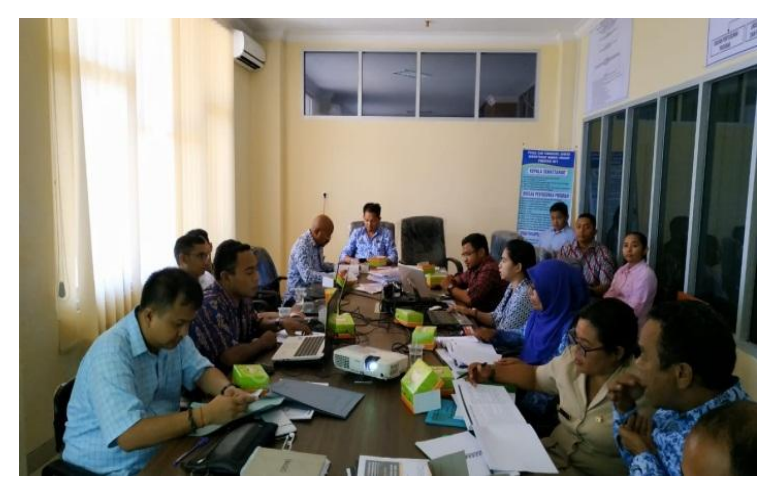

Gambar 3.6 Sosialisasi Hasil Identifikasi dan Inventarisasi serta pelatihan penggunaan Data Base dengan Instansi Pengguna.

\section{KESIMPULAN}

Pengabdian kepada masyarakat ini bertujuan untuk memberikan informasi kepada Instansi terkait berkaitan dengan lokasi dan kondisi sungai dan bangunan utama pada daerah irigasi kewenangan Provinsi di Pulau Timor sehingga informasi yang diberikan dapat berguna dalam melakukan usulan kegiatan perbaikan atau pemeliharaan terhadap bangunan yang sudah ada ataupun perbaikan jika terjadi kerusakan pada bangunan irigasi yang sudah ada.

Kegiatan pengabdian ini dilakukan selama 3 minggu. Dari pelaksanaan kegiatan ini kita dapat mengetahui besarnya debit air dan kondisi sungai serta bangunan utama yang merupakan sumber utama untuk mengalirkan air di lahan irigasi. Konsultasi dengan masyarakat juga dilakukan sehingga para pelaksana kegiatan pengabdian ini dapat menyalurkan keluhan masyarakat mengenai keterpenuhan kebutuhan air pada lahan irigasi masyarakat kepada Instansi Terkait.

\section{DAFTAR PUSTAKA}

Peraturan Menteri Pekerjaan Umum dan Perumahan Rakyat Republik Indonesia Nomor 14/PRT/M/2015 Tentang Kriteria dan Penetapan Status Daerah Irigasi.

Suseno A dan Agus R, Penggunaan Quantum GIS dalam Sistem Informasi Geografis, Bogor 2012. 